\title{
Kebijakan Hukum Pidana terhadap Pengguna Narkotika sebagai Korban Bukan Pelaku Tindak Pidana: Studi Lapangan Daerah Jambi
}

\author{
Hafrida*
}

\begin{abstract}
Abstrak
Tujuan jangka panjang yang ingin dicapai dalam kebijakan hukum pidana melalui peraturan perundang-undangan adalah memposisikan pengguna narkotika sebagai 'korban' yang membutuhkan rehabilitasi baik medis maupun sosial, bukan sebagai pelaku kriminal yang dijatuhi pidana penjara dan dimasukkan ke lembaga pemasyarakatan. Hal ini sangat penting mengingat data BNN menunjukan $80 \%$ pengguna narkotika adalah remaja. Provinsi Jambi sepanjang tahun 2011 menempati urutan ke-13 wilayah terbesar penyalahgunaan narkotika. Pengguna narkotika menurut Undang-Undang Nomor 35 Tahun 2009 tentang Narkotika menempatkan pelaku pengguna narkotika sebagai pelaku tindak pidana sebagaimana dirumuskan dalam Pasal 127 ayat (1) huruf a yang menyebutkan bahwa pengguna narkotika diancam dengan pidana penjara maksimal 4 (empat) tahun. Tulisan ini bersifat empiris (empirical research) berdasarkan penelitian lapangan di Pengadilan Negeri Jambi, BNN Provinsi Jambi, RSJ Jambi, dan LSM Granat. Analisis dilakukan terkait perumusan kebijakan hukum pidana dalam memandang pelaku pengguna narkotika sebagai korban tindak pidana. Data lapangan menunjukkan bahwa hampir $99 \%$ putusan hakim pengadilan negeri terhadap pengguna narkotika masih berupa pidana penjara walaupun $92 \%$ hakim pada Pengadilan Negeri se-Provinsi Jambi mengatakan bahwa pidana penjara bukan merupakan tindakan yang tepat, sementara putusan hakim merupakan gerbang utama dalam penanggulangan tindak pidana.
\end{abstract}

Kata kunci: kebijakan hukum pidana, korban, narkotika, penyalahguna narkotika, rehabilitasi.

\section{Criminal Law Policy on Drug Abuser as Victim in Lieu of Criminal Suspect: Field Study in Jambi}

\begin{abstract}
The long term goal sought after by criminal law policy through legislation is to put drug abusers in the position of victims in need of rehabilitations both medically and socially, and not as criminals who have to be sentenced and sent to the jail. This shift of paradigm is important as the data from Indonesian National Narcotics Board shows that out of $80 \%$ of the drug abusers are mostly teenagers; and in 2011, Jambi Province ranked 13th in Indonesia as the region with the biggest number of drug abusers. Drug abusers, according to Law Number 35 Year 2009 on Narcotics, are positioned as criminals. As formulated in the Article 127 (1) a, drug abusers are sentenced withthe maximum of 4 (four) years of prison. The field data shows that almost $99 \%$ of the sentences passed by the judges in district courts are still in

PADJADJARAN Jurnal IImu Hukum Volume 3 Nomor 1 Tahun 2016 [ISSN 2460-1543] [e-ISSN 2442-9325]

* Dosen Fakultas Hukum Universitas Jambi, Jl. Jambi-Ma. Bulian Km.15, Mendalo Darat Jambi, hafrida.nurdin@yahoo.com, S.H. (Universitas Lampung), M.H. (Universitas Indonesia).
\end{abstract}


the form of prison sentences, although almost 92\% Judges in Jambi District Courts argue that jail time are not the proper legal sentence for drug abusers. This is quite unfortunate since judicial verdicts should be the main gate of the criminal law prevention. Therefore, the drug abusers should be seen as victim instead of criminals.

Keywords: criminal law policy, victim, drugs, drugs abuser, rehabilitation.

\section{A. Pendahuluan}

Hasil penelitian tahun $2013^{1}$ menunjukkan bahwa: Pertama, profil Putusan Hakim Pengadilan Negeri (PN) di Provinsi Jambi menunjukan 99\% putusan hakim terhadap penyalahgunaan narkotika merupakan kriminal dengan hukuman pidana penjara; Kedua, 92\% hakim menyatakan bahwa pidana penjara tidak tepat untuk diterapkan pada pengguna narkotika; Ketiga, hakim dalam memutus perkara pengguna narkotika bergantung pada dakwaan jaksa penuntut umum yang terkadang tidak mendakwa tersangka dengan Pasal 127 ayat (1) huruf a Undang-Undang Nomor 35 Tahun 2009 tentang Narkotika (UU Narkotika). Ketika majelis hakim berpendapat bahwa terdakwa terbukti melanggar Pasal 127 ayat (1) huruf a UU Narkotika, hakim tidak dapat memutus berdasarkan pasal tersebut karena tidak terdapat dalam dakwaan jaksa penuntut umum (dakwaan jaksa penuntut umum adalah Pasal 111, 112, dan Pasal 114); Keempat, jaksa penuntut umum hampir selalu mendakwa tersangka penyalahgunaan narkotika dengan dakwaan berlapis yaitu Pasal 111 dan Pasal 112 UU Narkotika terkait penyimpanan, kepemilikan, dan penguasaan narkotika, serta Pasal 114 yaitu menawarkan untuk menjual, membeli atau menjadi perantara, karena setiap pengguna narkotika hampir selalu memiliki, menyimpan, dan membeli narkotika untuk kepentingannya sendiri. Berdasarkan hasil penelitian pada tahun pertama, dapat disimpulkan bahwa permasalahan penerapan pidana penjara justru disebabkan pada tataran normatif (peraturan perundangundangannya) yang menempatkan pengguna narkotika sebagai pelaku kriminal.

Berdasarkan hasil penelitian tersebut, rekomendasi yang dirumuskan antara lain adalah: Pertama, revisi terhadap UU Narkotika mutlak diperlukan terutama pengkajian terhadap rumusan Pasal 127 ayat (1) huruf a dan Pasal 128 ayat (1) huruf a tentang pengguna narkotika. Pasal tersebut mengkriminalisasi orang tua/wali yang dengan sengaja tidak melaporkan anaknya yang merupakan pengguna/pecandu dan diancam pidana penjara 6 bulan dan denda paling sedikit Rp. 100.000.000,00. ${ }^{2}$ Pasal ini mengkriminalisasi pengguna narkotika dan menjadi

1 Penelitian dengan judul "Analisis Putusan Hakim Pengadilan Negeri terhadap Perkara Pengguna Narkotika di Provinsi Jambi" yang didanai secara "Tahun Jamak". Artikel ini merupakan hasil penelitian lanjutan pada tahun kedua.

2 Pasal 128 ayat (1) Undang-Undang Nomor 35 Tahun 2009 tentang Narkotika (UU Narkotika): "Orang tua atau wali dari pecandu yang belum cukup umur, sebagaimana dimaksud dalam Pasal 55 ayat (1) yang sengaja tidak 
penyebab utama penjatuhan pidana penjara terhadap pengguna narkotika, walaupun hakim berpendapat bahwa pidana penjara tidaklah tepat diterapkan terhadap pengguna narkotika, melainkan rehabilitasi dan pendekatan yang humanis lebih tepat bagi mereka. Kedua, revisi terhadap UU Narkotika perlu juga dilakukan terhadap perumusan Pasal 111 dan Pasal 112 terkait penyimpanan, kepemilikan, dan penguasaan. Terkait perumusan Pasal 114 tentang pembelian, harus ditegaskan bahwa yang dimaksud memiliki, menguasai, menyimpan, dan membeli narkotika yang dapat dipidana adalah kegiatan-kegiatan tersebut dengan tujuan untuk mengedarkan lebih lanjut bukan untuk kepentingan memakai. Ketiga, revisi terhadap Pasal 128 ayat (1) tentang orang tua yang dengan sengaja tidak melaporkan anaknya sebagai pecandu diancam dengan pidana penjara paling lama 6 (enam) bulan perlu dilakukan karena partisipasi masyarakat khususnya partisipasi orang tua dalam penanggulangan pengguna narkotika tidak akan tercapai jika melalui ancaman pemidanaan.

Berdasarkan hasil penelitian pada tahun pertama sebagaimana diuraikan di atas, putusan pemidanaan dengan pidana penjara terhadap pengguna merupakan alternatif terakhir yang tidak terlaksana dikarenakan peraturan perundangan yang ada dalam Pasal 127 ayat (1) huruf a memberikan ancaman pidana penjara bagi pelaku pengguna narkotika meskipun secara personal hakim PN yang memutus perkara pengguna narkotika menyadari bahwa pemidanaan bukanlah alternatif yang tepat dalam pemberian sanksi bagi pelaku pengguna karena penerapan rehabilitasi dan pendekatan persuasif serta kekeluargaan merupakan perlakuan yang lebih baik.

Penerapan pidana penjara (kriminalisasi terhadap pengguna) bertentangan dengan tujuan UU Narkotika yang dirumuskan dalam Pasal 4, yaitu:

a. menjamin ketersediaan narkotika untuk kepentingan pelayanan kesehatan dan/atau pengembangan ilmu pengetahuan dan teknologi;

b. mencegah, melindungi, dan menyelamatkan bangsa Indonesia dari penyalahgunaan narkotika;

c. memberantas peredaran gelap dan prekursor narkotika; dan

d. menjamin pengaturan upaya rehabilitasi medis dan sosial bagi pengguna dan pecandu narkotika.

Pada pasal tersebut terlihat bahwa yang harus diberantas adalah peredaran gelap narkotika dan prekursor narkotika, bukan justru mengkriminalkan pelaku pengguna narkotika. Pengguna narkotika merupakan korban dari peredaran gelap narkotika. Pada Pasal 4 huruf d UU Narkotika disebutkan bahwa negara harus menjamin rehabilitasi medis dan sosial bagi pengguna dan pecandu narkotika, bukan justru mengkriminalkan pengguna melalui penjatuhan pidana penjara. 
Peraturan perundang-undangan yang mendukung upaya pemberantasan tindak pidana narkotika sangat diperlukan, apalagi tindak pidana narkotika merupakan salah satu bentuk kejahatan inkonvensional yang dilakukan secara sistematis, menggunakan modus operandi yang tinggi, teknologi canggih, dilakukan dengan terorganisir (organized crime), dan sudah bersifat transnasional (transnational crime). Tindak pidana narkotika berdasarkan UU Narkotika diberikan sanksi pidana cukup berat, di samping itu dapat juga dikenakan hukuman badan dan pidana denda, namun dalam kenyataanya para pelaku justru semakin meningkat. $\mathrm{Hal}$ ini disebabkan oleh penjatuhan sanksi pidana yang tidak memberikan dampak atau deterrent effect terhadap para pelakunya, khususnya terhadap pengguna narkotika.

Pada penelitian tahun kedua akan dilanjutkan dengan penelitian tentang "Kebijakan Hukum Pidana melalui Upaya Non Penal Berupa Rehabilitasi terhadap Pengguna Narkotika" yang pada akhirnya hasil penelitian ini dapat mewujudkan reformasi hukum bidang narkotika melalui revisi UU Narkotika. Penelitian ini sangat diperlukan mengingat kejahatan narkotika sudah melewati batas-batas negara (transnational organized crimes), oleh sebab itu untuk mengatasi kejahatan narkotika tidak dapat hanya dilakukan oleh satu instansi saja (kepolisian), tetapi diperlukan peran serta seluruh instansi terkait disertai dengan peran aktif masyarakat dalam memberikan informasi tentang kejahatan narkotika yang terjadi. Berbagai data dan informasi menunjukkan bahwa jika masalah narkotika ini tidak segara diatasi, maka Indonesia akan segara menjadi negara dengan pengguna narkotika kelima terbesar di dunia.

Permasalahan penyalahgunaan narkotika ini sangat serius mengingat tindakan ini dapat menimbulkan korban, maka harus diberikan perhatian serius dan perlindungan hukum yang layak. Begitu juga terhadap para korban dari kejahatan narkotika ini tentunya menimbulkan banyak korban. Berbeda dengan korban kejahatan lainnya, korban kejahatan narkotika justru dipandang sebagai pelaku. Pada berbagai negara seperti Inggris atau Australia, para pengguna narkotika dikategorikan sebagai korban bukan sebagai pelaku, oleh karenanya para pengguna narkotika akan segera diberikan fasilitas untuk rehabilitasi dan ditangani oleh para ahli. Pada Pasal 4 huruf e UU Narkotika, disebutkan bahwa negara menjamin pengaturan upaya rehabilitasi medis dan sosial bagi pengguna dan pecandu narkotika. Pecandu narkotika dan pengguna seharusnya dipandang sebagai orang yang sakit dan perlu rehabilitasi dan pengobatan.

Upaya pemerintah dalam penanggulangan keberadaan narkotika secara ilegal dalam masyarakat terus dilakukan sejak diberlakukannya UU Narkotika. Sebenarnya istilah narkotika tidak asing lagi bagi semua lapisan masyarakat seiring dengan sosialisasi tentang bahaya narkotika yang dilakukan oleh pemerintah melalui Instruksi Presiden Nomor 12 Tahun 2011 tentang Pelaksanaan Kebijakaan 
dan Strategi Nasional Pencegahan dan Pemberantasan Penyalahgunaan dan Peredaran Gelap Narkoba Tahun 2011-2015 (Inpres 12/2011) baik melalui sosialisasi, penyuluhan, seminar, dan pemberitaan media cetak maupun elektronik, dengan harapan membebaskan Indonesia dari peredaran dan penyalahgunaan narkotika pada tahun $2015 .{ }^{3}$ Adapun bentuk perlindungan hukum penyalahgunaan narkotika terhadap para pelaku dapat meliputi Pencegahan Pemberantasan Penyalahgunaan dan Peredaran Gelap Narkoba (P4GN) di seluruh lapisan masyarakat agar gerakan untuk menentang atau menolak penyalahgunaan dan peredaran gelap narkotika dapat secara sadar dilakukan oleh masyarakat. Program P4GN tidak hanya bersifat pencegahan terhadap bahaya penyalahgunaan narkotika, akan tetapi meliputi kegiatan pengobatan bagi pengguna narkotika berupa kegiatan rehabilitasi bagi pecandu narkotika dan korban pengguna narkotika. Hal tersebut sejalan dengan apa yang tercantum dalam Pasal 4 huruf $d$ UU Narkotika yang diatur lebih lanjut dalam Peraturan Pemerintah Nomor 25 Tahun 2011 tentang Pelaksanaan Wajib Lapor Pecandu Narkotika.

Pengaturan rehabilitasi berdasarkan Pasal 1 angka 13 UU Narkotika menjelaskan pelaku sebagai pecandu narkotika adalah orang yang menggunakan atau menyalahgunakan narkotika dan dalam keadaan ketergantungan pada narkotika, baik secara fisik maupun psikis. Pada Pasal 1 angka 15 dijelaskan bahwa pelaku sebagai pengguna adalah orang yang menggunakan narkotika tanpa hak atau melawan hukum.

Data Badan Narkotika Nasional (BNN) memperlihatkan bahwa sepanjang tahun 2011, Provinsi Jambi menempati urutan ke-13 wilayah terbesar dalam penyalahgunaan narkotika. Data BNN Provinsi Jambi juga menyebutkan bahwa selama tahun 2011, terdapat 441 orang narapidana yang tersandung kasus narkoba, 613 orang terkena AIDS, dan 100 orang menjadi pasien rumah sakit jiwa (RSJ) akibat narkoba. Ada pula 1.000 korban narkoba yang dibina berbagai Lembaga Swadaya Masyarakat (LSM) dan ada 174 kasus narkoba yang ditangani oleh Polda Jambi. "Jika satu orang mempunyai jaringan 20 orang, artinya pengguna narkoba di Jambi mencapai 46.560 orang", ungkap Kepala Badan Narkotika Nasional Provinsi (BNNP) Jambi, Kombespol M. Yamin. Bahkan dari hasil survei BNN 2012, Jambi termasuk daerah paling rawan/strategis untuk dijadikan pintu keluar masuk narkotika. Dari 9 (sembilan) kabupaten dan 2 (dua) kota di Jambi, tercatat 4 (empat) daerah (satu kota dan tiga kabupaten) menjadi basis bagi pengguna maupun peredaran narkoba. Keempat daerah itu adalah Kota Jambi, Kabupaten Bungo, Kabupaten Sarolangun, dan Kabupaten Tanjab Barat. Jika diurut berdasarkan ranking, menurut beliau, Kota Jambi menempati urutan pertama daerah paling rawan penggunaan dan peredaran narkoba di Jambi, disusul Kabupaten Bungo,

3 Badan Narkotika Nasional, “Pemberantasan Narkotika“, Jurnal BNN, Edisi Khusus 2009, hlm. 1. 
Kabupaten Sarolangun, dan Kabupaten Tanjab Barat. ${ }^{4}$

\section{B. Putusan Hakim Pengadilan Negeri Terhadap Pengguna Narkotika di Provinsi Jambi}

Penelitian putusan hakim PN terhadap pengguna narkotika di PN se-Provinsi Jambi dilaksanakan di 5 (lima) pengadilan negeri dari 10 (sepuluh) PN yang ada. Penelitian lapangan dilakukan di 5 (lima) PN yang dimaksud. Berdasarkan hasil wawancara yang dilakukan pada 10 (sepuluh) orang hakim, maka dapat dideskripsikan sebagai berikut: Profil putusan hakim terhadap pengguna narkotika menunjukan bahwa 99\% dijatuhi hukuman pidana penjara. Hal ini menunjukkan bahwa penerapan pidana penjara masih merupakan primadona di kalangan hakim di Indonesia. Fakta yang muncul di persidangan sering berbeda antara tuntutan penuntut umum dengan keterangan terdakwa. Penuntut umum menuntut bahwa unsur membawa, menguasai, dan memiliki narkotika dengan jumlah yang sangat terbatas, yakni di bawah ketentuan Surat Edaran Mahkamah Agung Nomor 4 Tahun 2010 tentang Penempatan Penyalahgunaan, Korban Penyalahgunaan, dan Pecandu Narkotika ke Dalam Lembaga Rehabilitasi Medis dan Rehabilitasi Sosial (SEMA 4/2010), yaitu kondisi tertangkap tangan dengan barang bukti di bawah 1 gram untuk sabu, 8 butir untuk ekstasi, dan 5 gram untuk ganja, yang merupakan kebutuhan satu hari), dengan ancaman pidana pasal pengedar. Keterangan terdakwa menyatakan bahwa yang bersangkutan hanya menggunakan alasan penuntut umum dengan berpedoman pada berkas perkara yang sudah terkonstruksi pasal terkait membawa, menguasai, dan memiliki yang diperuntukkan bagi pengedar. Hal ini terjadi di beberapa PN dimana jaksa penuntut umum tidak mendakwa dengan Pasal 127 ayat (1) huruf a UU Narkotika tentang pengguna dan cenderung menggunakan pasal yang lain yang pidananya lebih berat.

Hal ini terjadi karena penegak hukum menginterpretasikan bahwa memiliki, menguasai dan membawa narkotika di bawah ketentuan SEMA 4/2010 yang dapat dikonstruksi dalam pasal sebagai pengedar, sehingga sangat jarang pasal pengguna berdiri sendiri. Di sisi lain, penegak hukum yang menangani kasus pengguna narkotika jarang melakukan langkah-langkah pemeriksaan secara medis dan psikis (wawancara hakim) untuk menentukan seorang yang ditangkap sebagai pengguna atau pengedar, serta tidak pernah melakukan pemeriksaan terhadap tingkatan kecanduan dan rencana terapi rehabilitasinya, sehingga hakim merasa sulit dalam memutuskan tindakan berupa rehabilitasi. Hal ini menunjukkan bahwa para penegak hukum yang memeriksa perkara narkotika kurang memahami tujuan ${ }^{5}$ dari

\footnotetext{
Jambi Independen, 18 Januari 2012.

Pasal 4 UU Narkotika bertujuan:

a.menjamin ketersediaan narkotika untuk kepentingan pelayanan kesehatan dan/atau pengembangan ilmu pengetahuan dan teknologi;
} 
UU Narkotika. Berdasarkan tujuan UU Narkotika sebagaimana yang dirumuskan pada Pasal 4, maka yang harus diberantas adalah peredaran gelap narkotika, sedangkan pengguna harus dijamin rehabilitasinya, baik medis maupun sosial.

Pengguna narkotika (end user) justru menjadi korban dari ketidakmampuan negara dalam memberantas peredaran gelap narkotika yang akibatnya pengguna menjadi objek eksploitasi dari peredaran gelap narkotika tersebut. Selain itu, pengguna narkotika juga menjadi korban dalam sistem pemberantasan peredaran narkotika melalui UU Narkotika dimana terjadi dualisme dalam memandang pengguna narkotika di satu sisi, dan di sisi lain memandang pengguna narkotika sebagai pecandu yang harus ditempatkan dalam rehabilitasi medis dan sosial sebagaimana diatur dalam Pasal 103 UU Narkotika:

(1) Hakim yang memeriksa perkara pecandu narkotika dapat:

a. memutus untuk memerintahkan yang bersangkutan menjalani pengobatan dan/atau perawatan melalui rehabilitasi jika pecandu narkotika tersebut terbukti bersalah melakukan tindak pidana narkotika; atau

b. menetapkan untuk memerintahkan yang bersangkutan menjalani pengobatan dan/atau perawatan melalui rehabilitasi jika pecandu narkotika tersebut tidak terbukti bersalah melakukan tindak pidana narkotika.

(2) Masa menjalani pengobatan dan/atau perawatan bagi pecandu narkotika sebagaimana dimaksud pada ayat (1) huruf a diperhitungkan sebagai masa menjalani hukuman.

Sementara itu, data penelitian berdasarkan hasil wawancara hakim PN merupakan sebagai berikut:

1. Kesulitan hakim dalam menentukan terdakwa sebagai pengguna atau bukan karena berkas dari penyidik tidak dilengkapi keterangan dari dokter yang menyatakan yang bersangkutan sebagai penyalahguna/pecandu yang memerlukan perawatan medis;

2. Pada suatu perkara terbukti bahwa terdakwa sebagai pengguna sebagaimana yang diatur dalam Pasal 127 ayat (1) huruf a UU Narkotika, tetapi jaksa penuntut umum tidak mendakwa dengan pasal tersebut. Sebagaimana dikemukakan oleh Hakim T. Oyong, S.H., M.H., hakim PN Jambi, yang menyatakan persepsi berbeda antara hakim dan jaksa penuntut umum tentang pengertian pengguna narkotika menjadikan perkara menjadi rumit. Hal ini terjadi pada perkara narkotika di PN Kuala Tungkal, Muara Bulian dan Sengeti yang hakimnya memutuskan pelanggaran Pasal 111 dan 112 tentang kepemilikan, penyimpanan, dan penguasaan narkotika, serta Pasal 114 tentang jual beli narkotika. Hal ini terjadi karena perumusan Pasal 111, 112 dan Pasal 114 UU Narkotika bersifat ambigu.

\footnotetext{
b. mencegah, melindungi, dan menyelamatkan bangsa Indonesia dari penyalahgunaan narkotika;

c. memberantas peredaran gelap narkotika dan prekursor narkotika; dan

d. menjamin pengaturan upaya rehabilitasi medis dan sosial bagi pengguna dan pecandu narkotika.
} 
Pasal ini seperti pasal karet yang dapat diterapkan terhadap siapapun yang membeli, memiliki, menyimpan, dan menguasai narkotika sekalipun itu untuk konsumsi sendiri karena ketergantungan atau kecanduan. Pasal ini seharusnya diperuntukkan bagi penjual, pembeli, penyimpan, penguasaan, pemilik, dan penyimpan narkotika dengan tujuan untuk peredaran gelap narkotika bukan untuk konsumsi sendiri;

3. Sebanyak $99 \%$ putusan hakim menunjukan putusan PN terhadap pengguna narkotika merupakan pidana penjara, tetapi hasil wawancara terhadap hakim PN menyatakan 92\% responden menyatakan bahwa tidak tepat menjatuhkan pidana penjara bagi pengguna narkotika, rehabilitasi adalah lebih baik diterapkan. Sebanyak $8 \%$ responden menyatakan bahwa penerapan pidana penjara adalah tepat untuk tujuan penjeraan;

4. Penanggulangan terhadap pengguna narkotika tidak dapat dicapai melalui pidana penjara karena penanganan yang salah terhadap pengguna narkotika akan membuat mereka semakin buruk;

5. Penanggulangan pengguna narkotika harus lebih mengedepankan maksud dan tujuan dari pembentukan UU Narkotika karena yang ingin diberantas adalah peredaran gelap narkotika, sedangkan pengguna merupakan korban dari peredaran gelap narkotika;

6. Pencegahan dan penyelamatan bangsa melalui penyelamatan korban. Pengguna narkotika harus lebih dipandang sebagai korban, bukan sebagai pelaku pidana sehingga rehabilitasi medis sosial lebih tepat diterapkan dibandingkan pidana penjara.

Selain itu, ketentuan Pasal 127 ayat (1) huruf a dan Pasal 103 Pada UU Narkotika merupakan pasal yang saling melengkapi, yaitu:

1. Jika seorang pengguna narkotika/pecandu terbukti melakukan tindak pidana narkotika, maka hakim dapat memutus untuk memerintahkan yang bersangkutan untuk menjalani pengobatan dan/atau perawatan melalui rehabilitasi;

2. Jika seorang pengguna narkotika/pecandu tidak terbukti melakukan tindak pidana narkotika, maka hakim melalui ketetapannya memerintahkan yang bersangkutan untuk menjalani pengobatan dan/atau perawatan melalui rehabilitasi.

Pada kenyataannya, seharusnya ketentuan Pasal 127 ayat (1) huruf a tidak perlu diterapkan. Hakim dalam memutus perkara pengguna narkotika yang melanggar Pasal 127 ayat (1) huruf a, harus memperhatikan dan mengutamakan ketentuan Pasal 103 UU Narkotika. Berdasarkan kewenangan yang dijelaskan pada Pasal 103 UU Narkotika, hakim dapat memerintah terdakwa untuk menjalani rehabilitasi sekalipun jaksa penuntut umum tidak mendakwa dengan Pasal 127 ayat (1) huruf a, 
sehingga pengenaan sanksi pidana terhadap pengguna narkotika harus ditinjau dalam dimensi yang lebih luas karena pengguna narkotika bukanlah kriminal.

Kriminalisasi terhadap pengguna narkotika adalah tidak tepat, menurut Soerjono Soekanto: ${ }^{6}$

"kriminalisasi merupakan tindakan atau penetapan penguasa mengenai perbuatan-perbuatan tertentu yang oleh masyarakat atau golongan-golongan masyarakat dianggap sebagai perbuatan yang dapat dipidana menjadi perbuatan pidana atau membuat suatu perbuatan menjadi perbuatan kriminal dan karena itu dapat dipidana oleh pemerintah dengan cara kerja atas namanya."

Menurut definisi tersebut, suatu perbuatan yang dapat di kriminalisasi adalah suatu perbuatan yang menurut masyarakat dianggap sebagai suatu perbuatan yang dapat dipidana. Berbagai hal harus dipertimbangkan secara menyeluruh dalam menetapkan kriminalisasi terhadap suatu perbuatan ataukah dalam menetapkan untuk mendekriminalisasi. Moeljatno memandang bahwa terdapat tiga kriteria yang harus diperhatikan dalam proses kriminalisasi dalam konteks pembaharuan hukum pidana, yaitu: ${ }^{7}$ Pertama, penetapan suatu perbuatan sebagai perbuatan terlarang (perbuatan pidana) harus sesuai dengan perasaan hukum yang hidup dalam masyarakat; Kedua, apakah ancaman pidana dan penjatuhan pidana itu adalah jalan yang utama untuk mencegah dilanggarnya larangan-larangan tersebut; Ketiga, apakah pemerintah dengan melewati alat-alat negara yang bersangkutan mampu untuk benar-benar melaksanakan ancaman pidana kalau ternyata ada yang melanggarlarangan.

Penetapan suatu perbuatan menjadi suatu perbuatan pidana harus mengingat asas subordinaritas dalam hukum pidana. Dalam menetapkan suatu perbuatan sebagai suatu tindak pidana ataupun tidak harus melalui suatu penyelidikan tentang efektivitas penggunaan sanksi pidana dalam penanggulangan suatu kejahatan. Hukum pidana harus ditempatkan sebagai ultimum remedium (senjata pamungkas) dalam penanggulangan kejahatan yang menggunakan instrumen penal, bukan sebagai primum remedium (senjata utama) untuk mengatasi masalah kriminalitas.

Dalam formulasi tindak pidana terdapat dua sisi yang saling berhubungan yaitu pelaku tindak pidana pada satu sisi dan korban tindak pidana pada sisi yang lain. Dalam Declaration of Basic Principles of Justice for Victims of Crime and Abuse of Power disebutkan:

"Victims means person who, individually or collectively, have suffered harm, including physical or mental injury, emotional suffering, economic loss or

\footnotetext{
Soerjono Soekanto, Kriminologi: Suatu Pengantar, Cetakan Pertama, Jakarta: Ghalia Indonesia, 1981, hlm. 62. Moeljatno, Azas-azas Hukum Pidana, Jakarta: PT. Bina Cipta, 1985, hlm. 5.
} 
substantial impairment of their fundamental right, through acts or omissions that are in violation of criminal law as operative within member states, including those laws proscribing criminal abuse power."

Korban dari suatu tindak pidana memiliki hak yang dilindungi oleh undangundang. Hak tersebut diatur dalam Undang-Undang Nomor 13 Tahun 2006 tentang Perlindungan Saksi dan Korban. Tidak dapat kita pungkiri bahwa tindak pidana narkotika merupakan perbuatan pidana yang sangat serius dan membutuhkan upaya yang tegas dalam penanggulangan tindak pidana narkotika. Lain halnya terhadap pengguna narkotika yang harus dipandang sebagai hal yang berbeda. Pada berbagai negara, telah banyak yang menempatkan para pengguna/pecandu nakotika sebagai korban dan tidak lagi sebagai pelaku tindak pidana atau kriminal. Pandangan tehadap pemakai sebagai korban akan memiliki implikasi yang jelas terhadap perlakuan bagi pemakai/pecandu itu sendiri. Dengan memandang mereka sebagai korban, para pengguna narkotika dapat segera direhabilitasi dan ditangani oleh para ahli yang dibekali oleh kompetensi yang cukup.

\section{Kebijakan Rehabilitasi terhadap Pengguna Narkotika di Provinsi Jambi}

Keberadaan UU Narkotika semakin mengaburkan hak rehabilitasi bagi pengguna narkotika baik rehabilitasi sosial maupun medis. Kriminalisasi terhadap pengguna narkotika ${ }^{9}$ membawa dampak buruk bagi pengguna narkotika. Hasil penelitian pada tahun pertama, profil putusan hakim terhadap pengguna narkotika menunjukan $99 \%$ berupa pidana penjara. Hal ini menunjukkan bahwa kebijakan hukum pidana melalui dekriminalisasi terhadap pengguna narkotika adalah suatu hal yang harus dengan sungguh-sungguh mendapatkan perhatian. BNN pada Minggu 26 Januari 2014, mencanangkan tahun 2014 sebagai tahun penyelamatan pengguna narkoba, sebagai tindak lanjut kebijakan dekriminalisasi dan depenalisasi pengguna narkotika untuk mengantisipasi dan menekan jumlah pengguna narkotika.

Konsep dekriminalisasi sudah diatur pada Pasal 54 UU Narkotika. Pada pasal ini dijelaskan bahwa para pecandu narkotika wajib mendapatkan layanan rehabilitasi, sedangkan pada Pasal 103 disebutkan bahwa hakim dapat memutuskan dan menetapkan pecandu dan korban pengguna narkotika untuk menjalani pengobatan atau perawatan. Pada Pasal 127 ayat (3) dijelaskan bahwa dalam memutus perkara terhadap pengguna narkotika, hakim wajib memperhatikan ketentuan sebagaimana dimaksud dalam Pasal 54, Pasal 55, dan Pasal 103.

\footnotetext{
Deklarasi Perserikatan Bangsa Bangsa Nomor:A/Res/40/34 Tahun 1985.

Pasal 127 UU Narkotika:

Setiap pengguna:

a. Narkotika Golongan bagi diri sendiri dipidana dengan pidana penjara paling lama 4 (empat) tahun;

b. Narkotika Golongan II bagi diri sendiri dipidana dengan pidana penjara paling lama 2 (dua) tahun; dan

c. Narkotika Golongan III bagi diri sendiri dipidana dengan pidana penjara paling lama 1 (satu) tahun.
} 
Kerangka dekriminalisasi juga sudah diaktualisasikan pada Peraturan Pemarintah Nomor 25 Tahun 2011 tentang Pelaksanaan Wajib Lapor Pecandu Narkotika disenyebutkan bahwa Institusi Penerima Wajib Lapor (PP IPWL), tepatnya pada Pasal 13 ayat (4). Pada isi pasal tersebut dijelaskan bahwa sejak tahapan penyidikan, penuntutan, dan pengadilan sekalipun, pengguna narkotika berhak untuk ditempatkan di pusat rehabilitasi agar menjalani pemulihan. Hal ini berdasarkan hasil rekomendasi dari tim assessment yang memastikan bahwa orang tersebut merupakan pecandu atau pengguna narkoba murni.

Hasil wawancara Hakim PN Jambi Mansyur Bustami, S.H., M.H. dan Mahfudin, S.H., M.H. menyebutkan bahwa: ${ }^{10}$

1. Pengaturan dalam UU Narkotika memungkinkan untuk menjatuhkan pidana penjara pada pelaku pengguna narkotika, ${ }^{11}$ namun alternatif terbaik bagi pengguna narkotika adalah rehabilitasi;

2. Pengguna narkotika bukanlah kriminal, mereka adalah korban yang membutuhkan bantuan untuk terbebas dari pengaruh narkotika;

3. Seharusnya hakim tidak perlu menjatuhkan pidana penjara tetapi memerintahkan pada pengguna narkotika untuk direhabilitasi;

4. Sebaiknya pengguna narkotika tidak perlu bersentuhan dengan proses peradilan pidana tetapi sebaiknya langsung menjalani pengobatan dan rehabilitasi; dan

5. Diperlukan lembaga khusus untuk penempatan dan rehabilitasi pengguna narkotika, karena tidak tepat jika mereka ditempatkan di rumah sakit jiwa.

Hasil penelitian pada tahun pertama menunjukan bahwa 99\% putusan hakim pengadilan negeri terhadap pengguna narkotika adalah pidana penjara walaupun hasil wawancara menunjukan $92 \%$ hakim pengadilan negeri tidak setuju dengan penerapan pidana penjara terhadap pengguna narkotika. Hal ini disebabkan jaksa selalu mendakwa dengan Pasal 127 UU Narkotika, sehingga hakim tidak mempunyai alternatif lain selain menjatuhkan pidana penjara. Hakim seharusnya dapat memerintahkan atau menetapkan kewajiban rehabilitasi dengan memperhatikan ketentuan Pasal 54, 55, dan Pasal 103 UU Narkotika, dan tidak perlu semata-mata tergantung dengan dakwaan jaksa.

Data yang berasal dari BNN (termasuk BNN Provinsi dan Kota di Jambi) dan Granat Provinsi Jambi menunjukan bahwa:

1. Rehabilitasi adalah upaya terbaik bagi pengguna narkotika;

2. Menempatkan pengguna ke dalam penjara akan memperburuk kondisi pengguna narkotika; dan

3. Tidak perlu ada proses pemeriksaan melalui jalur pengadilan bagi pengguna narkotika untuk segera ditempatkan dalam pusat-pusat rehabilitasi.

10 Wawancara di Pengadilan Negeri Jambi pada 20 Agustus 2014.

$11 \quad$ Lihat Pasal 127 ayat (1) UU Narkotika. 
Penempatan pengguna narkotika pada rehabilitasi medis dan sosial diatur dalam SEMA 04/2010 ke dalam lembaga rehabilitasi medis dan rehabilitasi sosial. Terkait hal hakim menjatuhkan pemidanaan berupa perintah untuk dilakukan tindakan hukum berupa rehabilitasi atas diri terdakwa, majelis hakim harus menunjuk secara tegas dan jelas tempat rehabilitasi terdekat dalam amar putusannya. Tempat-tempat rehabilitasi dimaksud adalah:

1. Lembaga rehabilitasi medis dan sosial yang dikelola dan/atau dibina dan diawasi oleh BNN;

2. Rumah sakit Ketergantungan Obat (RSKO) Cibubur;

3. RSJ di seluruh Indonesia (di bawah Kementerian Kesehatan RI);

4. Panti Rehabilitasi Departemen Sosial RI dan Unit Pelaksana Tekhnis Daerah (UPTD); dan

5. Tempat-tempat rujukan lembaga rehabilitasi yang diselenggarakan oleh masyarakat yang mendapat akreditasi dari Kementerian Kesehatan atau Kementerian Sosial (dengan biaya sendiri).

Berdasarkan peraturan ini, maka penempatan pengguna narkotika dapat diperintahkan oleh hakim melalui keputusannya pada tempat-tempat yang telah ditetapkan, namun dari data penelitian lapangan pada RSJ Jambi menunjukan bahwa peserta rehabilitasi yang sedang dilaksanakan di RSJ Jambi adalah peserta yang datang sendiri (rehabilitasi sukarela) dan tidak terdapat peserta rehabilitasi yang berasal dari perintah hakim pengadilan (rehabilitasi paksa) sebagaimana dalam tabel berikut ini:

Tabel 1:

Distribusi Jumlah Pengguna Narkotika pada RSJ Jambi

\begin{tabular}{|c|c|c|}
\hline No. & Tahun & Jumlah \\
\hline 1 & Januari-Februari 2013 & 26 \\
\hline 2 & Maret-April 2013 & 32 \\
\hline 3 & Mei-Juni 2013 & 28 \\
\hline 4 & Juli-Agustus 2013 & 30 \\
\hline 5 & September-Oktober 2013 & 38 \\
\hline 6 & November-Desember 2013 & 52 \\
\hline 7 & Januari- Februari 2014 & 54 \\
\hline 8 & Maret- April 2014 & 54 \\
\hline 9 & Mei- Juni 2014 & 54 \\
\hline 10 & Juli 2014 & 50 \\
\hline
\end{tabular}

Sumber: Data Lapangan RSJ Agustus 2014

Dari tabel tersebut terlihat fluktuasi jumlah pengguna narkotika yang dengan kesadaran sendiri datang ke RSJ untuk mendapatkan rehabilitasi medis. Jumlah pengguna pada tabel di atas membiayai sendiri rehabilitasi yang dilakukan. Kondisi ini tidak sejalan dengan amanat tujuan Pasal 4 UU Narkotika dimana dalam Pasal 4 
huruf $d$ menyatakan: "Menjamin pengaturan upaya rehabilitasi medis dan sosial bagi pengguna dan pecandu narkotika".

Pada ketentuan dalam UU ini, negara menjamin upaya rehabilitasi medis dan sosial, tetapi dalam kenyataannya para pengguna dan keluarganya menanggung sendiri biaya rehabilitasi mereka. Jika kita memandang pengguna sebagai korban dari tindak pidana, maka sudah seharusnya negara bertanggung jawab atas rehabilitasi bagi korban narkotika. Pengguna narkotika merupakan perwujudan ketidakmampuan negara dalam melindungi warga negaranya sehingga menjadi korban dari peredaran gelap narkotika.

Pada PP IPWL disebutkan bahwa Institusi Penerima Wajib Lapor tempat wajib lapor adalah pusat kesehatan masyarakat, rumah sakit, dan/atau lembaga rehabilitasi medis dan sosial yang ditunjuk oleh pemerintah. Di Provinsi Jambi, institusi yang ditetapkan sebagai tempat wajib lapor adalah sebagai berikut:

1. BNN Provinsi dan BNN Kota Jambi;

2. Rumah Sakit Umum Daerah (RSUD) Raden Mattaher Jambi;

3. RSJ Jambi;

4. Puskesmas Tanjung Pinang;

5. Rumah sakit Bayangkara;

6. Rumah Sakit Tanjabbar; dan

7. Rumah Sakit Muara Bulian.

Institusi kesehatan tersebut di atas merupakan institusi penerima wajib lapor, sehingga pecandu dan pengguna narkotika dapat mendatangi institusi tersebut dan kemudian institusi tersebut akan membantu dalam proses rehabilitasi selanjutnya.

Pada Inpres 12/2011, fokus bidang rehabilitasi yaitu berupa pembangunan kapasitas lembaga rehabilitasi medis dan sosial secara prioritas berdasarkan kerawanan daerah penyalahgunaan narkotika, yakni sebagai berikut:

a. Upaya mengintensifkan wajib lapor pecandu narkotika;

b. Upaya memberikan pelayanan rehabilitasi medis dan sosial kepada pengguna, korban penyalahgunaan, dan pecandu narkoba;

c. Upaya pembangunan kapasitas lembaga rehabilitasi medis dan sosial secara prioritas berdasarkan kerawanan daerah penyalahgunaan narkoba; dan

d. Upaya pembinaan lanjut kepada mantan pengguna, korban penyalahgunaan, dan pecandu narkoba.

Metode Therapeutic Community (TC) merupakan metode pelayanan rehabilitasi yang diterapkan di lingkungan BNN. Pada metode TC, pertolongan diri (self help approach) merupakan kunci penting perubahan perilaku dan psikologis dalam konteks pembelajaran sosial. Seluruh anggota komunitas, termasuk didalamnya staf dan residen berupaya dan berperan bersama untuk menuju suatu pemulihan pola hidup yang sehat dan produktif. Komponen esensial dari suatu metode TC mencerminkan filosofi, norma, nilai, dan tujuan TC. Masing-masing 
komponen digunakan untuk terciptanya suatu proses pembelajaran sosial, mempromosikan bentuk hubungan interpersional yang sehat, dan mendukung terjadinya perubahan diri. Program TC dilaksanakan melalui penyelenggaraan perangkat TC, yaitu berbagai norma, nilai, dan kegiatan yang dilakukan untuk merubah perilaku pecandu secara menyeluruh.

\section{Kebijakan Depenalisasi terhadap Pengguna Narkotika}

Pola pikir yang menyamaratakan antara pengguna narkotika dengan pihak yang melakukan perdagangan gelap narkotika akan semakin memperburuk masa depan korban peredaran gelap narkotika dan berpotensi melanggar hak mereka sebagai manusia. Sebagaimana dikemukakan sebelumnya, korban pengguna narkotika ini terbesar pada usia remaja dan anak-anak. Kebijakan terhadap korban perdagangan gelap narkotika seharusnya hanya melalui pendekatan rehabilitasi baik kesehatan maupun sosial semata. Sarana dan tempat pemulihan serta upaya masyarakat untuk membantu pemulihan seharusnya dibantu oleh pemerintah sebagai bentuk penyediaan hak kesehatan bagi masyarakatnya tanpa perlu ditakut-takuti dengan pemidanaan.

Penyadaran masyarakat untuk membantu mereka keluar dari jeratan narkotika perlu dilakukan dengan inisiasi, bukan menakut-nakuti dengan ancaman pemidanaan. Kewenangan penanganan terhadap korban peredaran gelap narkotika lebih sesuai bila diberikan kepada pihak yang mengurusi bidang kesehatan, sosial, pemberdayaan masyarakat, dan bukan bidang penegakan hukum, sehingga pendekatan dapat dilakukan dengan lebih humanis dan upaya pemulihan yang jauh dari keterpaksaan.

Pembaharuan hukum melalui pembaharuan UU Narkotika sebagai bagian dari kebijakan kriminal yang bertujuan menjadikan hukum pidana menjadi lebih baik dan sesuai dengan nilai-nilai yang ada dalam masyarakat sebagaimana dikemukakan Barda Nawawi Arief: ${ }^{12}$

a. Pembaharuan hukum pidana pada hakikatnya bagian dari upaya untuk mengatasi masalah-masalah sosial (termasuk masalah kemanusiaan) untuk mencapai atau menunjang tujuan nasional (kesejahteraan masyarakat dan sebagainya);

b. Sebagai bagian dari kebijakan kriminal, pembaharuan hukum pidana pada hakikatnya bagian dari upaya perlindungan masyarakat (khususnya upaya penanggulangan kejahatan); dan

c. Sebagai bagian dari kebijakan penegakan hukum, pembaharuan hukum pidana pada hakikatnya bagian dari upaya pembaharuan substansi hukum (legal substance) dalam rangka lebih mengefektifkan penegakan hukum.

12 Barda Nawawi Arief, Bunga Rampai Kebijakan Hukum Pidana, Jakarta: Prenada Kencana, 2008, hlm. 31-32. 
Pembaharuan hukum pidana pada hakikatnya merupakan upaya untuk melakukan peninjauan dan penilaian kembali nilai-nilai sosio-politik, sosiofilososfis, dan sosio-kultural masyarakat Indonesia yang didasarkan pada muatan normatif dan substantif hukum pidana yang dicita-citakan. Pembaharuan hukum pidana sudah saatnya dilakukan jika suatu peraturan perundangan sudah tidak effektif lagi. Suatu perundangan dianggap sudah tidak efektif apabila:

a. Sebagian besar masyarakat tidak mentaatinya lagi; dan

b. Ketaatan masyarakat hanya karena takut dikenakan sanksi.

Menurut Achmad Ali, dengan mengutip H. C. Kelman, terdapat berbagai jenis ketaatan terhadap hukum, yaitu:

a. Ketaatan yang bersifat compliance, yaitu jika seseorang menaati peraturan hanya karena ia takut terkena sanksi, kelemahan ketaatan jenis ini adalah diperlukannya pengawasan yang terus menerus;

b. Ketaatan yang bersifat identification, yaitu jika seseorang menaati suatu peraturan hanya karena takut hubungan dengan pihak lain menjadi rusak; dan

c. Ketaatan yang bersifat internalization, yaitu jika seseorang menaati peraturan benar-benar hanya karena ia merasa bahwa aturan itu sesuai dengan nilai-nilai yang dianutnya. ${ }^{13}$

Seseorang dapat menaati hukum bisa hanya berdasarkan satu jenis ketaatan saja, atau karena kombinasi dua ketaatan atau ketiganya. Jika ketaatan masyarakat terhadap hukum telah diabaikan, maka sudah saatnya dilakukan upaya pembaharuan hukum. Begitu pula terhadap UU Narkotika, terdapat beberapa pasal yang harus dilakukan revisi dikarenakan pasal-pasal tersebut sudah tidak memiliki keberlakuan dalam masyarakat. Kebijakan kriminal yang paling mendesak adalah dekriminalisasi terhadap pengguna narkotika. Di berbagai negara yang telah melakukan dekriminalisasi menunjukan terjadinya penurunan jumlah pemula pemakai narkotika. Dekriminalisasi dimana pemerintah mendorong para pecandu/pengguna untuk memberdayakan dirinya melalui perawatan atau rehabilitasi.

Pada Pasal 57 UU Narkotika, disebutkan bahwa, "Selain melalui pengobatan dan/atau rehabilitas medis, penyembuhan pecandu narkotika dapat diselenggarakan oleh instansi pemerintah atau masyarakat melalui pendekatan keagamaan dan tradisional". Penggunaan kata-kata 'dapat' sebagaimana dirumuskan dalam pasal tersebut memberikan peluang bagi pemerintah untuk melepaskan kewajibannya dalam memberikan jaminan rehabilitasi medis dan/atau sosial sebagaimana diatur dalam Pasal 4 huruf d tentang tujuan UU ini.

Rehabilitasi korban peredaran gelap narkotika merupakan suatu pendekatan yang menyeluruh dan komprehensif. Berdasarkan pengertian korban yang

$13 \quad$ Ibid., hlm. 348. 
tercantum dalam Pasal 1 angka 2 Undang-Undang Nomor 13 Tahun 2006 tentang Perlindungan Saksi dan Korban (UU PSK) dinyatakan bahwa korban adalah seseorang yang mengalami penderitaan fisik, mental, dan/atau kerugian ekonomi yang diakibatkan oleh suatu tindak pidana. Korban adalah mereka yang menderita jasmani dan rohaninya sebagai akibat tindakan orang lain yang bertentangan dengan kepentingan diri sendiri atau orang lain yang mencari pemenuhan kepentingan diri sendiri atau orang lain yang bertentangan dengan kepentingan hak asasi yang menderita.

Kebijakan dekriminalisasi dan depenalisasi pengguna narkotika merupakan amanat konvensi internasional dan hasil sidang PBB mengenai narkotika, yakni pengguna narkoba diberi alternatif penghukuman berupa rehabilitasi dan negaranegara peserta sidang untuk menyiapkan sumber daya manusia dan fasilitasnya untuk merehabilitasi pengguna narkoba. Hasil konvensi ini diadopsi dalam UU Narkotika. Pada Pasal 103 yang diberi kewenangan kepada hakim untuk menetapkan hukuman rehabilitasi. Masa rehabilitasi dihitung sama dengan menjalani hukuman, sehingga rehabilitasi merupakan hukuman atau sanksi bagi pengguna narkotika. Dekriminalisasi pengguna narkotika diartikan dengan menggunakan narkotika bagi diri sendiri, dan tetap diancam dengan hukuman pidana (Pasal 127 UU Narkotika). Namun demikian, sanksi yang dijatuhkan tersebut tidak berupa pidana penjara, melainkan rehabilitasi.

Memandang pengguna sebagai korban tentunya tidak muncul secara tiba-tiba. Dapat dikemukakan di sini bahwa konsep tersebut dilatarbelakangi oleh fakta di lapangan bahwa pengguna narkotika yang dikirim ke lembaga pemasyarakatan merupakan salah satu bentuk pembinaan. Kondisi tersebut ternyata tidak meyelesaikan masalah, bahkan cenderung menciptakan masalah baru. Para pengguna yang awalnya hanya coba-coba, ketika berada di lembaga pemasyarakatan mereka berinteraksi dengan pengguna yang sudah senior dan bahkan para bandar. Pada akhirnya banyak dari mereka yang menjadi lebih pintar dalam penyalahgunaan narkotika setelah keluar dari penjara. Bahkan tidak jarang mereka menjadi pengedar baru. Oleh karena itu, kerangka pemikiran tentang depenalisasi merupakan suatu hal yang sangat perlu dipertimbangkan.

Kebijakan hukum pidana Indonesia saat ini memberi posisi yang sama atau menyamaratakan pengguna narkotika, termasuk pecandu dengan pelaku perdagangan gelap narkotika (produsen, pengedar, penjual) adalah pola pikir yang tidak tepat. Pada suatu tindak pidana, selalu ada dua pihak yakni pelaku yang harus mempertanggungjawabkan perbuatan pidananya dan pihak korban yang harus dilindungi hak-haknya. Begitu pula halnya dalam peredaran gelap narkotika yang seharusnya beranjak dari konsep pemikiran bahwa pengedar gelap narkotika adalah pelaku tindak pidana narkotika yang harus mempertanggungjawabkan 
perbuatannya, dan pihak pengguna merupakan korban yang harus dilindungi hakhaknya.

Pada kerangka depenalisasi, pengguna narkotika tetap dinyatakan melanggar hukum, namun pada tahapan penyidikan, penuntutan dan pengadilan, sang penegak hukum dapat mengambil langkah sehingga pada akhirnya pengguna narkoba dijatuhi hukuman rehabilitasi sesuai dengan kadar ketergantungannya. Konsep depenalisasi sudah ditunjukkan dengan spirit UU Narkotika, khususnya pada pengaturan Pasal 28 ayat (2) dan (3) beserta aturan turunan lainnya. Secara konseptual dalam kerangka depenalisasi, mengonsumsi narkotika tetap merupakan hal yang melanggar hukum. Ketika pengguna narkoba ini melaporkan dirinya kepada IPWL, baik di puskesmas atau rumah sakit yang sudah ditunjuk Kementerian Kesehatan $\mathrm{RI}$, maka orang tersebut bisa lepas dari tuntutan pidana. Dekriminalisasi dan depenalisasi diyakini betul dapat menjadi solusi dalam menurunkan prevalensi pengguna. Untuk memperkuat langkah di atas, perlu dilakukan dua hal: Pertama, penilaian yang maksimal; dan Kedua, perlunya sinergi atau keterpaduan oleh seluruh lembaga penegak hukum yang ada.

Pada Pasal 13 ayat (4) PP IPWL dijelaskan bahwa sejak tahap penyidikan, penuntutan, dan pengadilan sekalipun, korban penyalahgunaan narkoba berhak untuk mendapatkan pemulihan di pusat rehabilitasi dengan mengacu hasil rekomendasi tim penilai. Dekriminalisasi maupun depenalisasi tetap menyatakan penyalahgunaan narkoba sebagai pelanggaran hukum. Penegak hukum bisa mengambil keputusan yang bijaksana sehingga korban dijatuhi hukuman rehabilitasi sesuai dengan kadar ketergantungannya. Sementara untuk kebijakan depenalisasi, korban bisa terlepas dari tuntutan pidana ketika melakukan wajib laporke IPWL.

Dari uraian tersebut maka bentuk rehabilitasi yang dapat diterapkan pada pengguna narkotika adalah sebagai berikut:

1. Rehabilitasi sukarela yang dilaksanakan terhadap pengguna narkotika yang dengan sukarela melaporkan diri dan mengajukan permintaan untuk direhabilitasi; atau

2. Rehabilitasi paksa yang diterapkan berdasarkan putusan hakim. Rehabilitasi paksa sesungguhnya merupakan sanksi yang diterapkan bagi pelaku pengguna narkotika yaitu sanksi berupa rehabilitasi.

Bentuk rehabilitasi sukarela ataupun paksa harus difasilitasi dan dijamin pelaksanaannya oleh pemerintah. Hal ini merupakan amanat dari Pasal 4 huruf e UU Narkotika yakni, "Menjamin pengaturan upaya rehabilitasi medis dan sosial bagi pengguna dan pecandu narkotika". Pengguna narkotika harusnya menyadari bahwa rehabilitasi merupakan upaya penyembuhan bagi dirinya yang dijamin oleh negara dan para pengguna narkotika merasa dilindungi oleh negara. 


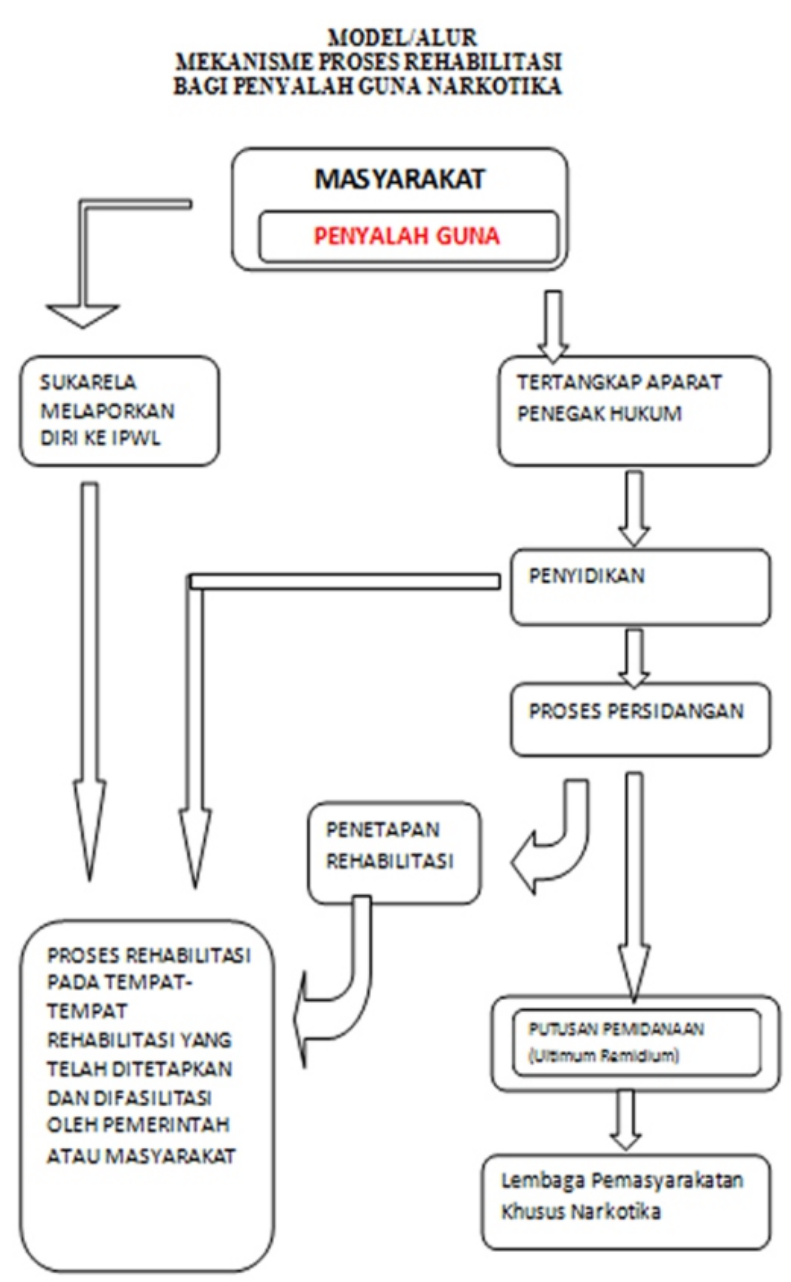

\section{E. Penutup}

Berdasarkan uraian yang disampaikan, kesimpulan yang dapat diambil adalah: Pertama, 99\% putusan hakim PN Jambi terhadap pengguna narkotika adalah penjatuhan pidana penjara. Namun demikian, 92\% responden (Hakim PN Jambi) menyatakan bahwa tidak tepat menjatuhkan pidana penjara bagi penyalah guna narkotika, rehabilitasi adalah lebih baik diterapkan. Sebesar $8 \%$ responden menyatakan bahwa penerapan pidana penjara adalah tepat untuk tujuan penjeraan; Kedua, pengguna narkotika di Indonesia seharusnya tidak dipandang sebagai pelaku kriminal karena mereka merupakan korban, sehingga rehabilitasi medis maupun sosial perlu dilakukan. Rehabilitasi terhadap pengguna narkotika di Provinsi Jambi dapat berbentuk rehabilitasi sukarela yang dilakukan sendiri atas inisiatif korban dan keluarga korban narkotika dan rehabilitasi paksa yang diperintahkan oleh hakim pengadilan. Hasil penelitian menunjukan bahwa $100 \%$ rehabilitasi yang dilaksanakan merupakan rehabilitasi sukarela yang merupakan inisiasi sendiri dari pengguna dan dibiayai sendiri oleh pengguna; dan Ketiga, kebijakan hukum pidana Indonesia saat ini memberi posisi yang sama atau 
menyamaratakan pengguna narkotika, termasuk pecandu dengan pelaku perdagangan gelap narkotika (produsen, pengedar, penjual) adalah pola pikir yang tidak tepat. Dengan memperhatikan hal-hal tersebut, perlu adanya revisi UU Narkotika, khususnya penghapusan Pasal 127 terkait kriminalisasi pengguna narkotika karena pengguna narkotika adalah korban tindak pidana peredaran gelap narkotika yang tidak mampu dikendalikan oleh negara. Oleh sebab itu, pemerintahlah yang seharusnya berkewajiban untuk menyediakan/menjamin ketersediaan sarana dan prasarana rehabilitasi medis maupun sosial bagi mereka.

\section{Daftar Pustaka}

\section{Buku}

Barda Nawawi Arief, Bunga Rampai Kebijakan Hukum Pidana, PT. Citra Adytia Bhakti, Jakarta, 2002.

, Kebijakan Legislatif Dalam Penanggulangan Kejahatan Dengan

Pidana Penjara, Cetakan Kedua, Universitas Diponogoro, Semarang, 1996.

Bandung, 1998. Teori-Teori Dan Kebijakan Pidana, Edisi Revisi, Alumni,

Eva Achjani Zulfa dan Indriyanto Seno Adji, Pergeseran Paradigma Pemidanaan, Lubuk Agung, Bandung, 2010.

Moeljatno, Azas-azas Hukum Pidana, PT. Bina Cipta, Jakarta, 1985.

Soedarto, Hukum dan Hukum Pidana, Alumni, Bandung, 1986.

Soerjono Soekanto, Kriminologi: Suatu Pengantar, Cetakan Pertama, Ghalia Indonesia, Jakarta, 1981.

\section{Dokumen Lainnya}

Badan Narkotika Nasional, Pemberantasan Narkotika, Jurnal BNN, Edisi Khusus, Jakarta, 2009.

Jambi Independen, 18 Januari 2012.

\section{Dokumen Hukum}

Undang-Undang Nomor 35 Tahun 2009 Tentang Narkotika. 